(C) Е.В. Каргаполова, В.В. Войков, Ю.А. Давыдова

DOI: http://doi.org/10.15350/24097616.2020.2.02

\title{
УДК 374.1
}

\section{РЕГИОНАЛЬНЫЙ ШКОЛЬНЫЙ ТЕХНОПАРК В НАЦИОНАЛЬНОМ ПРОЕКТЕ «ОБРАЗОВАНИЕ»}

\author{
Е.В. Каргаполова, В.В. Войков, Ю.А. Давыдова
}

\begin{abstract}
Каргаполова Екатерина Владимировна, доктор социологических наук, профессор кафедры политологии и социологии, Российский экономический университет им. Г.В. Плеханова, Москва, Россия. РИНЦ SPIN-код: 3776-0757 E-mail: k474671@list.ru
\end{abstract}

Войков Владимир Владимирович, директор, Государственное автономное образовательное учреждение Астраханской области "Региональный школьный технопарк", Астрахань, Россия.

E-mail: vladimir.voykov@gmail.com

Давыдова Юлия Александровна, кандидат исторических наук, доцент кафедры политологии и социологии, Российский экономический университет им. Г.В. Плеханова, Москва, Россия. РИНЦ SPIN-код: 2967-8794

E-mail: ylkadav@mail.ru

\begin{abstract}
Аннотация. $B$ статье исследуется роль региональных школьных технопарков в реализации национального проекта «Образование». Развитие научно-технических компетениий школьника позиционируется как адекватный ответ российского общества вызовам техногенной иивилизации. Целью данного исследования является анализ позитивньхх эффректов деятельности школьных технопарков. Содержательную основу статьи составляет анализ научных источников по данной тематике и результатов конкретного сочиологического исследования методом анкетирования среди родителей посетителей регионального школьного технопарка Астраханской области. Авторы отмечают немаловажную роль школьных технопарков в реализации задач в предметной области «Технология»» Национального проекта «Образование», обеспечении национальной безопасности, совершенствовании инновачионной среды, системы образования; развитии человеческого капитала, одаренности, становлении новой интеллектуальной элиты. Результаты опроса показали, что значительная часть программ технопарка финансируется за счет бюджетных средств. Выявлены сочиально-демографические характеристики ребенка - посетителя технопарка в Астраханской области. Среди них преобладают мальчики с хорошей успеваемостью в основной средней школе, родители
\end{abstract}


которых состоят в зарегистрированном браке. Примечательно, что в традиционно полиэтничном регионе с тремя титульными нациями программы технопарка посещают, 8 основном, русские. Это отражсает рост сочиильных дистанций между национальныли группами в стратегиях воспитания и обучения детей. Авторы обрамают внимание на высокую мотивированность родителей в области интеллектуального развития ребенка, его научно-технических способностей и компетенций. Отмечается также, что значительная доля родителей планирует обучение ребенка после окончания школь за пределами региона, что свидетельствует о тендениии оттока из региона ее будущей научно-технической элиты.

Ключевые слова: региональныцй школьный технопарк, начиональная программа «Образование», дополнительное образование икольников, инженерно-техническое творчество, одаренные дети.

\title{
REGIONAL SCHOOL TECHNOPARK IN THE NATIONAL PROJECT «EDUCATION»
}

E.V. Kargapolova, V.V. Voikov, Y.A. Davydova

\author{
Ekaterina V. Kargapolova, \\ Doctor of sociological Sciences, Professor of political \\ science and sociology Russian economic University \\ by G. V. Plekhanov, Moscow, Russian Federation. \\ E-mail: k474671@ list.ru
}

Vladimir V. Voikov, Director of the regional school technopark, Astrakhan, Russian Federation. E-mail: vladimir.voykov@gmail.com

Yuliya A. Davydova, Candidate of historical Sciences, associate Professor of political science and sociology Russian economic University by

G. V. Plekhanov, Moscow, Russian Federation. e-mail: ylkadav@mail.ru

\begin{abstract}
The article investigates the role of regional school technoparks in implementing the national project "Education». The development of scientific and technical competencies of school students is positioned as an adequate response of Russian society to the challenges of technogenic civilization. The aim of this research is to analyze positive effects of school technoparks activity. The substantive basis of the article is the analysis of scientific sources on this topic and the results of a specific sociological study by questionnaire survey among parents of visitors to the Regional school technopark of the Astrakhan region. The authors note the important role of school technology parks in the implementation of objectives in the The National Project "Education" "Technology" subject area, ensuring national security, improving the innovation environment, the education system, the development of human capital, talent and the formation of a new intellectual elite. The results of the survey showed that a significant part of the technopark's programmes is financed from the budget. The social and demographic characteristics of a child visitor to a
\end{abstract}


technopark in Astrakhan region have been identified. Among them, predominant boys with good grades in the basic secondary school and whose parents are marrie. It is noteworthy that in the traditionally multi-ethnic region with three titular nations, the programs of the technopark are mainly attended by Russians. This reflects the growing social distance between national groups in parenting and education strategies. The authors pay attention to the high motivation of parents in the intellectual development of the child, his scientific and technical abilities and competencies. It is also noted that a significant share of parents are planning to educate their child after graduation from school outside the region, which indicates the trend of outflow future scientific and technical elite from the region.

Keywords: regional school technopark, national program "Education", additional education for schoolchildren, engineering and technical creativity, gifted children.

\section{Введение}

Целями национального проекта Российской Федерации «Образование» (2019-2024) являются «обеспечение глобальной конкурентоспособности российского образования, вхождение РФ в число 10 ведущих стран мира по качеству общего образования; воспитание гармонично развитой и социально ответственной личности на основе духовно-нравственных ценностей народов РФ, исторических и национально-культурных традиций» 1 . Для реализации данных целей в национальном проекте предусматривается решение десяти задач, в первой из которых заявляется «обновление содержания и совершенствование методов обучения предметной области «Технология»» ${ }^{2}$. Это свидетельствует о важности развития системы образования в данной предметной области по причине высоких темпов научнотехнического развития; требует новых знаний, умений и навыков у работников всех профессиональных сфер и, в первую очередь, инженерно-технической сферы. Но позитивные изменения в области подготовки научно-технических кадров затрудняются тем, что смена научно-технологических укладов опережает становление образовательных программ, а также избытком дешевой и зачастую некачественной информации. Сокращение научно-технической сферы уже приводит в современной России к снижению уровня подготовки учащихся в средней и высшей школе. Отставание от общемировых тенденций развития системы школьного и высшего образования в данных условиях должно рассматриваться как явная угроза национальной безопасности страны. Необходимо развитие системы профильного образования с привлечением академических и прикладных научноисследовательских институтов, поддержанное финансовым обеспечением с учетом накопленного опыта проектно-исследовательской деятельности и новых информационных образовательных интернет-технологий с возможностями построения индивидуальной траектории [21, с. 142].

Одной из эффективных форм организации научно-технического творчества молодежи стали технопарки. Современный технопарк - «это комплекс, включающий объекты, обеспечивающие возможности для реализации на своей базе функций обучения, организации производства, научных исследований, инфраструктуру, обеспечивающую выполнение задач, которые обычно выполняют деловые и выставочные центры... Технопарки относятся к субъектам научной и инновационной инфраструктуры, осуществляющих формирование условий, благоприятных для развития производства в научно-технической сфере при наличии оснащённой и экспериментальной базы и высокой концентрации квалифицированных кадров» [1, с. 74].

\footnotetext{
1 Национальный проект «Образование». - URL: https://strategy24.ru/rf/education/projects/ (режим доступа: 10.02.2020).

2 Национальный проект «Образование». - URL: https://strategy24.ru/rf/education/projects/ (режим доступа: 10.02.2020)
} 
Начало истории технопарков восходит к 50-60 гг. XX в., что было связано с развитием в ведущих странах мира высокотехнологичных отраслей экономики, и технопарки позиционировались как инструменты научно-технологического прогресса. В США, Китае, Индии рост сети технопарков обусловлен главным образом государственным финансированием, четкой правовой регламентацией, благоприятным инвестиционным климатом [13]. «В Европе, Канаде и Австралии работают около двухсот технопарков и бизнес-инкубаторов. В США их количество за 13 лет увеличилось более чем в 30 раз. В современной России известен опыт успешной работы технопарков при высших учебных заведениях и в системе Российской академии наук» [1, с 74]. В 2014 г. в России в системе высшей школы России действовало 76 технопарков, 21 технопарк получил государственнообщественную аккредитацию [13].

Исследователи подчеркивают необходимость развития сети школьных технопарков [1, с. $74 ; 5$, с. $28 ; 13]$. Небезосновательно отмечается, что «многие студенты знакомятся с наукой и исследованиями лишь на старших курсах университетов, однако могли бы начать знакомство еще в школе» [13].

Анализ немногочисленной отечественной научной литературы, посвященной школьным технопаркам, позволил выделить ряд позитивных эффектов их деятельности в различных сферах общественной жизни:

1) содействие реализации национальной безопасности страны путем подготовки кадров, «особенно кадров инженерных - ввиду сложности и технологичности современных высокоточных систем поражения, разведки, управления, связи и т.п.» [4, с. 144];

2) сохранение лучших традиций в созданной ранее и завоевавшей мировой авторитет системе отечественного образования (здоровый консерватизм в преподавании фундаментальных дисциплин) и открытость ко всем инновационным подходам в образовании, в частности проблемно-проектному подходу, профильному обучению, онлайновому образованию [2, с 209-210, 15, с. 66; 16, с. 70, 19, 21, с. 142-145];

3) модернизация образования путем концентрации высокотехнологичного современного оборудования, программных средств и информационных технологий, реализации принципов непрерывного образования в образовательных кластерах, которые представляют собой «совокупность взаимосвязанных учреждений дополнительного образования и вузов, связанных партнёрскими отношениями с предприятиями региона» [8, с. 157];

4) осуществление образовательного процесса на основе информационно-когнитивной и личностно ориентированной парадигм [4, с. 144]; обеспечение разумного баланса фундаментальности, универсальности знания и практико-ориентированности в удовлетворении потребности реальных секторов экономики $[14,17,21]$; формы и содержания. «К примеру, советская модель образования, сочетающая в себе разумную строгость рассуждений с простотой и доступностью материала, а также предпочтение содержательным, а не формальным конструкциям, представляет собой одну из лучших в мире на соответствующем этапе развития общества» [21, с. 145];

5) развитие инновационной среды путем формирования у школьников и преподавателей компетенций создания инновационного продукта, производственной и предпринимательской деятельности, преодоления разрыва между образованием, наукой и промышленностью [6, c. $108,8,12$, с. $117,13,18]$. Технопарки «позволяют объединить научную составляющую в виде технологических разработок, производственную составляющую в виде внедрения этих разработок в массовое производство, образовательную составляющую в виде целенаправленной и качественной подготовки будущих квалифицированных кадров, обеспечивающих научное проектирование технологических разработок и их внедрение в производство» [18]; 
6) подготовка нового поколения учёных, исследователей и рабочих для высокотехнологичных отраслей путем выявления одаренных детей и их ранней профориентации на этапе младшей школы [2; 3, с. 79-80; 5; 8, 10-12].

7) «Школьный технопарк это новая форма организации доступа учащихся и учителей к участию в технически сложных проектах, которые концентрируются на наиболее перспективных направлениях: робототехника, микроэлектроника, химия, биология, программирование... Намного интереснее и увлекательнее учить физику, биологию или химию в лаборатории, где можно провести эксперименты. Например, разработать роботизированную или компьютерную установку по обеспечению теплом, водой, интенсивностью освещения тепличный комплекс или даже просто теплицу у бабушки или родителей на даче...» [10].

Отдельно необходимо подчеркнуть позитивные эффекты деятельности школьных технопарков в области развития человеческого капитала:

1) социализация личности, способной к высокопроизводительному труду путем активного вовлечения учащихся общеобразовательных учреждений в практическую, научнотехническую, инженерно-конструкторскую и изобретательскую деятельность [2, с. 209-210, 8];

2) формирование мировоззрения творческой личности на основе целостного, системного понимания современной картины мира, усвоения межпредметных связей [8, с. 157-158] как альтернативы мировоззрению «вещеглота»-потребителя. «Среди всех трансформаций, переживаемых современным российским обществом, самая опасная - превращение в «общество потребления». Идеология «общества потребления» выбрала молодёжь как самую податливую социальную прослойку и требует превращения молодых людей в носителей утилитарно-гедонистических мировоззренческих установок. Юному человеку не дают возможности даже на мгновение выпасть из системы потребления, стирают все его идентичности, кроме идентичности приобретателя, сковывают его свободу и делают приложением к вещам (компьютерам, мобильным телефонам, музыкальным хитам, бестселлерам, блокбастерам)» [7, с. 20];

3) поощрение творческой инициативы, любознательности, самостоятельности в противовес убийственным эффектам систем тестирования и стандартизации [2, 21];

4) развитие навыков работы в команде [10], формирование сообществ резидентов с особой внутренней культурой для творческого взаимодействия, что формирует особое архитектурное пространство технопарков, кванториумов. «В каждом городе, где открывается новый «Кванториум», удается создать уникальный образ пространства, больше напоминающий «коворкинг», чем образовательное учреждение [20, с. 148].

Методика исследования. В предметной зоне нашего исследования анализ некоторых результатов деятельности регионального школьного технопарка (РШТ) Астрахани, который открылся в 2013 г. Это «первый на территории России детский технопарк, оснащенный высокотехнологичным оборудованием и специализирующийся в применении проектного подхода к погружению ребенка в мир инженерных профессий» ${ }^{3}$. РШТ позиционирует себя как «современный детский образовательный комплекс, предоставляющий своим учащимся уникальные условия для развития кругозора, способностей и навыков проектной деятельности в перспективных областях науки, техники и творчества/ За время своей деятельности РШТ помог тысячам астраханских детей развить свои технические и научные проекты, избавиться от страха публичных выступлений, принять участие в престижных федеральных конкурсах и соревнованиях, совершить осознанный выбор перспективной профессии и поступить в лучшие университеты страны и региона» ${ }^{4}$. В РШТ огромное

\footnotetext{
${ }^{3}$ Региональный школьный технопарк.- URL: https://schooltech.ru/\#

${ }^{4}$ Региональный школьный технопарк.- URL: https://schooltech.ru/\#
} 
внимание уделяется организации обратной связи с посетителями технопарка и их родителями на предмет анализа удовлетворенности качеством предоставляемых услуг, исследуются также социально-демографические, мотивационные, поведенческие особенности детей и их родителей. Основной метод исследования - социологический опрос методом анкетировния. С начала 2019 г. было опрошено 554 родителя и 563 школьника, что составляет более половины посещающих РШТ за один год и таким образом репрезентирует всех посетителей. В данной статье мы акцентируем внимание на анализе результатов анкетирования среди родителей.

\section{Результаты исследования.}

Ответы родителей дают возможность составить представление о социальнодемографических характеристиках детей - посетителей РШТ. Так, среди них практически в два раза больше мальчиков, чем девочек (65,9\% против 34,1\%). 13,6\% детей учатся в основном на «отлично», 48,9\% - в основном на «хорошо» и «отлично», 25\% - на «хорошо» и «удовлетворительно», только 3,4\% - в основном на «удовлетворительно». И 5,6\% родителей отказались и затруднились ответить на этот вопрос. Ответы свидетельствуют о том, что среди детей в подавляющем большинстве те, кто вполне успешно адаптирован к требованиям учебного процесса средних общеобразовательных школ.

Средний возраст ребенка - посетителя РШТ - составляет 11,6 лет, первого посещения программ дополнительного образования - 7,7 лет, первого посещения программ РШТ 11,2 года. По национальности существенно преобладают русские $(69,3 \%), 9,1 \%$ составляют казахи, остальные группы представлены в единичных случаях. В традиционно многонациональной Астрахани это отражает различные стратегии воспитания, обучения и профессиональной ориентации национальных групп, а также в значительной степени рост социальных дистанций по национальному признаку.

Анализ результатов анкетирования дает возможность составить представление о социально-демографических характеристиках родителей. Среди заполнявших анкету преобладают женщины (79,5\% против 20,5\%). Их средний возраст составил 40,2 года. Среди них $39,8 \%$ специалистов с высшим образованием, $8 \%$ руководителей с высшим образованием, по 6,8\% предпринимателей и рабочих и служащих без высшего образования, 4,5\% государственных служащих. Каждый десятый не работает, и также каждый десятый отказался конкретизировать род своей деятельности. $62,5 \%$ родителей имеют высшее образование, $14,8 \%$ - среднее техническое, 5,7\% - начальное профессиональное, 4,5\% среднее общее, $3,4 \%$ - послевузовское. 6,8\% по каким-то причинам отказались ответить на этот вопрос. Подавляющее большинство $(71,6 \%)$ опрошенных родителей состоят в браке, $19,3 \%$ разведены, 3,3\% холосты, 5,7\% отказались указать свое брачное состояние. 42\% имеют одного ребенка, по 27,3\% - по одному или трех и более детей.

Весьма примечательно, что $31,8 \%$ опрошенных категорически отказались ответить на вопрос о материальном положении семьи (табл. 1). Нуждается в дальнейшем исследовании анализ причин того, что значительная часть респондентов скрывает информацию о своем материальном положении. И полученные результаты по этому вопросу вряд ли можно считать репрезентативными. Тем не менее среди семей детей - посетителей технопарка - преобладают «необеспеченные», 11,4\% «зажиточных», по 10,2\% «обеспеченных» и «бедных», 4,5\% «богатых» и нет «нищих». 77,3\% родителей ответили, что их детям не приходилось подрабатывать (например, во время каникул), но уже 11,4\% отмечают, что приходилось и $11,4 \%$ затруднились и отказались ответить на этот вопрос.

Таблица 1.

Ответы родителей на вопрос «Как бы Вы охарактеризовали материальное положение Вашей семьи?» 


\begin{tabular}{|l|c|}
\hline \multicolumn{1}{|c|}{$\begin{array}{c}\text { Денег с трудом хватает даже на питание } \\
\text { («нищие») } \\
\text { («бедные») }\end{array}$} & 0,0 \\
\hline $\begin{array}{l}\text { На питание денег хватает, но покупка одежды вызывает затруднения } \\
\text { («едег хватает на питание и одежду, но купить сейчас телевизор, } \\
\text { холодильник или стиральную машину мы не можем } \\
\text { («нобеспеченные) }\end{array}$ & 27,3 \\
\hline $\begin{array}{l}\text { Денег хватает на крупную бытовую технику, но мы не могли бы купить } \\
\text { («обеспеченные») }\end{array}$ & 10,2 \\
\hline Денуюг машину хватает на все, кроме покупки недвижимости (квартиры или дачи) \\
\hline $\begin{array}{l}\text { («зажиточные») } \\
\text { Катериальных затруднений не испытываем. При необходимости могли бы } \\
\text { («богатые») }\end{array}$ & 11,4 \\
\hline Затрудняюсь ответить & 4,5 \\
\hline Отказ от ответа & 4,5 \\
\hline
\end{tabular}

На вопрос «Уверены ли Вы в осуществлении своих жизненных планов?» 30,7\% ответили однозначно «да», 44,3\% - «скорее да, чем нет». То есть данные категории опрошенных характеризуются тем, что достаточно адекватно смотрят в будущее, умеют планировать и реализовывать жизненные стратегии. Только 4,5\% ответили «скорее да, чем нет», 1,1\% - «нет». Но практически каждый пятый затруднился и отказался ответить на этот вопрос.

Очень важным представляется анализ мотивации родителей обучения ребенка по программам дополнительного образования технической направленности. При ответе родителей на вопрос «Оцените для чего, по Вашему мнению, ребенку необходимы занятия в РШТ?» первые три места распределились среди вариантов «Для интеллектуального развития» (4,88 баллов по пятибалльной шкале), «Для развития у ребенка способности изобретать» (4,78 балла), «Это оказывает значительное влияние на выбор ребенком профессии» (4,42 балла). Значительной также является мотивация социального характера «Чтобы развивать у ребенка желание приносить пользу людям (4,55 баллов), «Чтобы ребенок в будущем стал уважаемым специалистом своего дела» (4,39 баллов). Немаловажным в структуре мотивационного комплекса родителей является стремление рационального решения вопроса свободного времени ребенка, успешной адаптации в стремительно изменяющемся окружающем мире и снижения опасности интернет-зависимости, игровой зависимости у ребенка, которые, что показательно, набрали одинаковое количество баллов 4,38 по пятибалльной шкале. Вариант «Для повышения мотивации к учебе» набрал 4,25 баллов; варианты «Чтобы ребенок занял достойное место в коллективе сверстников», «Чтобы обеспечить ребенку материальный достаток в будущем через востребованную и хорошо оплачиваемую профессию» - по 4,2 балла; «Это помогает при поступлении ребенка в вуз» - 4,11 балла, «Для решения проблемы успеваемости в школе» - 3,8 баллов, «Для подготовки к сдаче ОГЭ и ГИА» $-3,58$ баллов.

При такой высокой степени мотивированности родителей неудивительно, что 35,2\% детей посещали программы (кружки, проекты, курсы) РШТ уже более трех раз, 6,8\% - три раза, $10,2 \%$ - два раза, $33 \%$ - один раз, и только $12,5 \%$ до этого ни разу. Тем более, что 46,6\% родителей ответили, что ребенок посещал программы РШТ бесплатно, 28,4\% - платно, и $15,9 \%$ родителей отметили вариант «и платно, и бесплатно».

При ответе на вопрос «Заинтересованы ли Вы в том, чтобы Ваш ребенок постоянно занимался в РШТ?» 86,4\% родителей ответили однозначно «да», $11,4 \%$ затруднились ответить, и лишь 2,5\% выбрали вариант «нет». Родителям также был задан вопрос «При 
наличии каких условий Ваш ребенок мог бы постоянно заниматься в РШТ?», на который были получены следующие ответы «при желании ребенка» $(84,1 \%)$, «при наличии свободного времени - много домашних заданий задают в школе» $(34,1 \%)$, «если бы участие в программах РШТ давало дополнительные баллы при поступлении в вуз» $(31,8 \%)$, «при наличии свободного времени, так как ребенок посещает другие учреждения дополнительного образования» (23,9\%), «при создании на базе РШТ Центра по подготовке к ОГЭ и ГИА, где ребенок мог бы заниматься с репетиторами» $(23,9 \%)$, «при наличии финансовых возможностей в семье на оплату занятий в РШТ» $(20,5 \%)$, «при организации конкурсов» (17\%), «при организации на базе РШТ занятий, которые полностью бы заменяли обучение в школе» $(13,6 \%)$, «при наличии лучших возможностей добираться на общественном транспорте» $(13,6 \%)$, «при наличии больших возможностей для занятий онлайн» $(5,7 \%)$.

При анализе ответов родителей на вопрос «По какой программе Ваш ребенок посещает (посетил) занятия в Региональном школьном технопарке (РШТ)?» можно составить представление о спектре направлений дополнительного образования, предоставляемых технопарком. Так, 23,8\% респондентов назвали направление «Первые шаги в робототехнике», $24,7 \%$ - «Основы криптографии», по 8,6\% - «Физика в опытах и исследовательских проектах», «3D принтеры», 8\% - «Радиотехническое конструирование», 7,9\% - «Архитектура и дизайн средствами 3D», 6,8\% - «WEB-програмирование». 22,3\% отметили направления, связанные с деятельностью детской телевизионной студии РШТ (журналистика, видеомонтаж, создание газеты РШТ, создание телепередачи, первые шаги в фотографировании для начинающих). Интересно отметить, что 6,8\% назвали такое направление как «Модное шитье». Некоторые родители при ответе на этот вопрос писали: «Ему нравиться заниматься!» или «У Рябицева», то есть указывали конкретного преподавателя, которому доверяют своего ребенка.

$47,7 \%$ родителей получают информацию о мероприятиях РШТ от ребенка, 39,8\% - из интернета, по $25 \%$ от друзей и сотрудников РШТ, $14,8 \%$ - в социальных сетях, $12,5 \%$ - в группе РШТ в социальных сетях, 8\% - из «Дневника.ру», 7,9\% - от коллег, по 6,8\% - от родственников и посредством телевидения, 5,7\% - из рекламных стендов, 2,3\% - по радио. На вопрос «По каким каналам Вам удобнее получать информацию постоянно о мероприятиях РШТ?» 53,4\% опрошенных ответили СМС-рассылка по телефону, 44,3\% - по электронной почте, $38,6 \%$ - в социальных сетях, группах, $11,3 \%$ - посредством мессенджеров (WhatsApp, Viber и др.).

O востребованности и перспективах развития направлений, кружков технопарка свидетельствуют ответы родителей на вопрос «Какие программы РШТ Ваш ребенок хотел бы еще посетить?». Практически половина $(48,9 \%)$ выбрали робототехнику, примерно каждый третий (по 34,1\%) - нанотехнологии, цифровое производство, трехмерное проектирование и дизайн и английский язык. Выбор последнего направления, входящего в перечень обязательных направлений средней школы, свидетельствует, на наш взгляд, о проблемах качества преподавания этого предмета в регионе. 30,6\% отметили для себя как перспективное направление интеллектуального развития ребенка информационные технологии, 29,5\% микроэлектронику, 28,4\% технологии «интеллектуального» здания («Умный дом»), 25\% физику, 23,9\% - электронику и радиотехническое конструирование. $21,6 \%$ респондент считает, что его ребенку будут интересны такие программы как «Волшебный объектив (фото-, видео)», по 17\% - «Биотехнологии» и (опять же) «Модное шитье», $15,9 \%$ - «Авиамоделирование», по 14,8\% - «Проекты научно-популярной телевизионной студии» и «Начальное техническое моделирование», 13,6\% - «Охота на лис (спортивное ориентирование)», 12,5\% - «Художественно-прикладное творчество», по 11,4\% - «Архитектура вокруг нас» и «Общетехническое моделирование», 10,2\% - «Судомодельное конструирование», 8\% - «Прикладные возобновляемые источники энергии», 6,8\% - 
«Дрегстер (автомодельный спорт)», по 5,7\% -«Студию дошкольного образования «УМКА», «Веселая риторика», «Юные корабелы (моделирование судов)».

Родителям был также задан и вопрос «Обучение по каким направлениям в РШТ было бы интересно Вашему ребенку помимо существующих программ?». По мнению практически половины $(48,9 \%)$ родителей это методы саморегуляции, примерно каждый третий назвал управление людьми, психологию и музыку, каждый третий-четвертый - общественную жизнь региона, страны, мира, культуру, искусство и английский язык, каждый четвертый литературу, каждый пятый - каждый домоводство (кулинарию, консервирование); пятыйшестой - здоровье, краеведение и финансовую грамотность, каждый шестой - спорт, каждый шестой-седьмой - вождение автомобиля. Только $5,7 \%$ родителей в условиях рыночной экономики считают, что ребенку будут полезны знания основ предпринимательства.

Интересным представлялось проанализировать ответы родителей на вопрос «В каких кружках, секциях, объединениях дополнительно занимался (занимается) помимо занятий (учёбы) в школе Ваш ребенок?». 50\% ответили, что это занятия спортом, 38,6\% - обучение иностранному языку, $18,2 \%$ - танцы, по 9,1\% успевают посещать художественную самодеятельность и другие технические кружки, 6,8\% - занятия рисованием, графикой.

Родителям был задан также вопрос «Готовы ли Вы перевести ребенка на домашнее обучение?», на который 79,5\% опрошенных ответили отрицательно, 14,8\% - затруднились ответить. Только 3,4\% ответили «да, готов» и ни один их опрошенных не выбрал вариант ответа «Мой ребенок уже обучается на домашнем обучении». Между тем только половина $(47,7 \%)$ ответили, что не пользуются услугами репетитора. Но уже $30,6 \%$ родителей ответили, что пользуются услугами репетитора по английскому языку, $15,9 \%$ - по математике, 7,9\% - по русскому языку. 22,7\% пользовались этими услугами уже в начальной школе, 25\% - в 5-8 классах, 9,1\% - в 9-11 классах.

Результаты анкетирования демонстрируют, что посетитель РШТ - ребенок интеллектуально развитый, в перспективе с большой долей вероятности этот ребенок мог бы пополнить научно-техническую элиту региона. Но насколько реализуема, по мнению родителей, эта перспектива именно в пределах региона? Анализ ответов родителей на вопрос «Каковы, по Вашему мнению, перспективы ребенка СРАЗУ после окончания школы?» проявляет, что примерно каждый третий $(34,1 \%)$ пока об этом не задумывался и затруднился ответить на этот вопрос. Только каждый четвертый $(26,1 \%)$ ответил, что его ребенок будет учиться в вузе Астраханской области, каждый шестой-седьмой планирует обучение в колледже Астраханской области. И каждый пятый планирует, что после окончания школы представитель будущей интеллектуальной научно-технической элиты уедет из региона учиться в вузе в другом регионе Российской Федерации.

Только 34,1\% родителей затруднились при ответе на вопрос «Необходимо ли Вашему ребенок посещение программ РШТ при обучении в вузе?». И только 3,4\% опрошенных считают, что в этом нет необходимости, так как уровень подготовки в современных вузах России достаточен, кроме того, ребенок будет учиться и работать одновременно, а у семьи нет финансовых возможностей оплачивать посещение дополнительных занятий в РШТ. Считают, что это необходимо, если в РШТ будут созданы условия для приобретения дополнительных профессиональных навыков, 33\% опрошенных; для развития навыков научной работы - 20,6\% респондентов. $13,6 \%$ отмечают данную необходимость в связи с тем, что в вузах сокращается аудиторная нагрузка и у ребенка может появиться свободное время. 5,6\% ответили, что это необходимо, так как в вузах наблюдается тенденция перевода обучения в формат он-лайн.

Заканчивая представление результатов нашего исследования, хотим отметить очень высокие оценки, которые дали родители деятельности сотрудников РШТ (табл. 2). И эти ответы заслуженные, учитывая неповторимую атмосферу СО-творчества, созданную в региональном школьном технопарке Астрахани. 
Ответы родителей на вопрос «Оиените занятия в РШТ по следующим критериям»

\begin{tabular}{|l|c|}
\hline \multicolumn{1}{|c|}{ Варианты ответов } & $\begin{array}{c}\text { средневзвешенная } \\
\text { балльная оценка по } \\
\text { пятибалльной шкале }\end{array}$ \\
\hline $\begin{array}{l}\text { Уникальность мероприятий РШТ, которые не имеют аналогов } \\
\text { в регионе }\end{array}$ & 4,64 \\
\hline Качество мероприятий (занятий) с детьми & 4,84 \\
\hline Уровень оборудования & 4,55 \\
\hline Эстетическое оформление помещений РШТ & 4,46 \\
\hline Творческая атмосфера & 4,87 \\
\hline Профессионализм педагогов & 4,97 \\
\hline
\end{tabular}

\section{Заключение.}

Подводя итоги вышесказанному, следует отметить:

1. сущность деятельности школьных технопарков заключается в содействии становлению новой интеллектуальной элиты, а смена элит происходит каждый раз во время смены технологических укладов.

2. наличие позитивных эффектов от деятельности школьных технопарков в различных сферах общественной жизни, в частности, в обеспечении национальной безопасности, совершенствовании инновационной среды, системы образования; развитии человеческого капитала.

3. важную роль школьных технопарков в обновлении содержания и совершенствовании методов обучения предметной области «Технология» в рамках Национального проекта «Образование».

\section{Литература:}

1. Аксёнов С.И., Кушнир А.М. Школьный мини-технопарк в опыте А.С. Макаренко // Народное образование. - 2012. - № 2 (1415). - C. 73-81. URL: https://elibrary.ru/item.asp?id=17637704

2. Андриянцева С.А., Лупова И.А., Красникова Е.М. Повышение уровня экологической культуры в рамках проектной деятельности школьников // Фундаментальные и прикладные исследования в области химии и экологии - 2018. Материалы международной научно-практической конференции. Отв. ред. Л. М. Миронович. - Курск: Юго-западный университет, 2018. - C. 209-211. URL: https://elibrary.ru/item.asp?id=35361057

3. Антонова М.В., Максимкина О.И Педагогическое сопровождение процесса социально-профессиональной ориентации младших школьников. // Вестник Московского городского педагогического университета. Серия: Педагогика и психология. - 2017. № 2 (40). - C. 76-82. URL: https://elibrary.ru/item.asp?id=29308332

4. Артамонова Е.Н Особенности развития техносферы в дополнительном образовании // Дискуссия. - 2012. - № 10. - C. 144-146. URL: https://elibrary.ru/item.asp?id=18017269

5. Валишин Ю.И., Гришаева Ю.М., Евстафьева Н.С. Педагогика культуры мира в ассоциированных школах ЮНЕСКО // Педагогическая тетрадь. Сборник статей и методических разработок учителей географии Московской области. - М.: Московский государственный областной университет, 2018. - C. 22-30. URL: https://elibrary.ru/item.asp?id=36533315

6. Гончаренко Ю.А. Школьный технопарк - одно из средств организации исследовательской деятельности // Психология и педагогика: методика и проблемы 
практического применения. - 2015. - № 42. - C. 107-110. URL: https://elibrary.ru/item.asp?id=22989274

7. Григорьев Д.В. Детско-взрослые общности и образовательные производства // Социальная педагогика. - 2012. - № 4. - C. 20-23. URL: https://elibrary.ru/item.asp?id=18028076

8. Евдокимов Ю.К., Салахова А.Ш., Кирсанов А.Ю. Дистанционные и виртуальные технологии в профильном обучении // Народное образование. - 2010. № 8 (1401). - C. 157-160. URL: https://elibrary.ru/item.asp?id=25440556

9. Евсеев В.О. Жизненное пространство как фактор формирования национального менталитета // Ученые записки Российского государственного социального университета. 2010. - № 7. C. 12-20. URL: https://elibrary.ru/item.asp?id=16523821

10. Есина М.И Роль образовательных учреждений в социально-экономическом развитии региона // Проблемы педагогики. - 2018. - №6 (38). - C. 69-70. URL: https://elibrary.ru/item.asp?id=36533315

11. Лим В.Г., Воеводин И.Г. Опыт внедрения системы дополнительного образования школьников в области информационной безопасности на базе образовательных организаций Астраханской области // Ученые записки ИУО РАО. - 2017. - № 3 (63). - С. 301-304. URL: https://elibrary.ru/item.asp?id=30744892

12. Литвинова С.В. Школьный технопарк как средство организации индивидуальной образовательной среды учащихся // На путях к новой школе. - 2015. - № 4. - C. 117-120. URL: https://elibrary.ru/item.asp?id=22989274

13. Маюрова А.С., Кустикова М.А., Маюрова М.В. Технопарки России - надежный партнер для образования // На путях к новой школе. - 2014. - № 2. - C. 93-95. URL: https://elibrary.ru/item.asp?id=22956859

14. Мельков С.А., Кошкин А.П., Микрюков В.О. Зачем переходить к кейсовому обучению? // Научные и образовательные проблемы гражданской защиты. - 2013. - № 2 (17). - C. 41-47. URL: https://elibrary.ru/item.asp?id=21501933

15. Морозова Н.А., Осипенко Л.Е. Системно-функциональный подход к анализу организации учебной проблемно-проектно- исследовательской деятельности в инженерных классах в рамках сетевого взаимодействия // Вестник PMAT. - 2018. - № 3. - С. 60-68. URL: https://elibrary.ru/item.asp?id=36885108

16. Немирич Т.Н., Маланов И.А. Допрофессиональная подготовка сельских школьников // Образование и право. - 2018. - № 12. - C. 268-277. URL: https://elibrary.ru/item.asp?id=38052794

17. Образование в современном российском регионе: качество, состояние, проблемы, тенденции / Е.В. Каргаполова, И.В. Аксютина, И.В. Беседина, Ю.Л. Дмитриева, Н.М. Качуровская, С.Б. Медведев, М.А. Семенова, С.А. Таран, Ю.А. Шуклина; под общ. ред. Е.В. Каргаполовой. - Волгоград: Волгоградское научное изд-во, 2013. - 194 с. URL: https://elibrary.ru/item.asp?id=25114894

18. Образовательный технопарк «ТЕМП»: концепция и модели воплощения / Е.А. Коузова, Е.А. Тюрина, М.И. Солодкова, Е.В. Сидорчук, Д.Ф. Ильясов, Т.А. Данельченко, Ф.А. Зуева, А.В. Ильина, А.В. Кисляков, А.В. Коптелов, С.А. Ларюшкин, Г.В. Яковлева; под ред. В.Н. Кеспикова. - Челябинск: ЧИППКРО, 2016. - 104 с. URL: https://elibrary.ru/item.asp?id=26547319

19. Порядина А.Ю. Проектная деятельность по химии со школьниками // Современные образовательные технологии в мировом учебно-воспитательном пространстве. - 2015. - № 1. - C. 118-123. URL: https://elibrary.ru/item.asp?id=25440556

20. Солодилов М.В. История и будущее архитектуры дополнительного образования на примере индустриального города - детский технопарк // Постиндустриальная среда российских мегаполисов. Сборник статей по материалам научно-технической 
конференции с международным участием. Под ред. М.В. Шувалова, Е.А. Ахмедовой, Т.В. Караковой. - Самара: Самарский государственный технический университет, 2020. - С. 140149. - URL: https://elibrary.ru/item.asp?id=42307370

21. Тюхов И.И., Шахраманьян М.А Профильное и онлайновое образование для подготовки кадров к работе в научно-технических областях г. Москвы // Вестник ВИЭСХ. 2016. - № 2 (23). - C. 142-147. URL: https://elibrary.ru/item.asp?id=28213227

\section{References:}

1. Aksenov S. I., Kushnir A. M. School mini-Technopark in the experience of A. S. Makarenko, Public education, 2012, no. 2 (1415), pp. 73-81. (In Russian) URL: https://elibrary.ru/item.asp?id=17637704

2. Andriantseva S. A., Lupova I. A., Krasnikova E. M. Improving the level of environmental culture in the framework of project activities of schoolchildren. Kursk, SouthWestern University Publ., 2018, pp. 209-211. (In Russian) URL: https://elibrary.ru/item.asp?id=35361057

3. Antonova M. V., Maksimkina O. and Pedagogical support of the process of social and professional orientation of younger students. Bulletin of the Moscow city pedagogical University. Series: Pedagogy and psychology, 2017, no. 2 (40), pp. 76-82. (In Russian) URL: https://elibrary.ru/item.asp?id=29308332

4. Artamonova E. N. Features of technosphere development in additional education. Discussion, 2012, no. 10, pp. 144-146. (In Russian) URL: https://elibrary.ru/item.asp?id=18017269

5. Valishin Yu. I., Grishaeva Yu. M., Evstafieva N. S. Pedagogy of the culture of peace in UNESCO associated schools. Moscow, Moscow state regional University Publ., 2018, pp. 22-30. (In Russian) URL: https://elibrary.ru/item.asp?id=36533315

6. Goncharenko Yu. A. School Technopark - one of the means of organizing research activities. Psychology and pedagogy: methods and problems of practical application, 2015, no. 42, pp. 107-110. (In Russian) URL: https://elibrary.ru/item.asp?id=22989274

7. Grigoriev D. V. Child-adult communities and educational productions. Social pedagogy, 2012, no. 4, pp. 20-23. (In Russian) URL: https://elibrary.ru/item.asp?id=18028076

8. Evdokimov Yu. K., Salakhova A. sh., Kirsanov A. Yu. Distance and virtual technologies in profile training. National education, 2010, no. 8 (1401), pp. 157-160. (In Russian) URL: https://elibrary.ru/item.asp?id=25440556

9. Evseev V. O. Vital space as a factor of formation of national mentality. Scientific notes of the Russian state social University, 2010, no. 7, pp. 12-20. (In Russian) URL: https://elibrary.ru/item.asp?id=16523821

10. Esina M. and the Role of educational institutions in the socio-economic development of the region. Problems of pedagogy, 2018, no. 6 (38), pp. 69-70. (In Russian) URL: https://elibrary.ru/item.asp?id=36533315

11. Lim V. G., Voevodin I. G. Experience of implementing the system of additional education of schoolchildren in the field of information security on the basis of educational organizations of the Astrakhan region. Scientific notes of IME RAE, 2017, no. 3 (63), pp. 301-304. (In Russian) URL: https://elibrary.ru/item.asp?id=30744892

12. Litvinova S. V. School Technopark as a means of organizing individual educational environment of students. On the way to a new school, 2015, no. 4, pp. 117-120. (In Russian) URL: https://elibrary.ru/item.asp?id=22989274

13. Mayurova A. S., Kustikova M. A., Mayurova M. V. Technoparks of Russia-a reliable partner for education. On the way to a new school, 2014, no.2, pp. 93-95. (In Russian) URL: https://elibrary.ru/item.asp?id=22956859 
14. Melkov S. A., Koshkin A. P., Mikryukov V. O. Why switch to case study? Scientific and educational problems of civil protection, 2013, no. 2 (17), pp. 41-47. (In Russian) URL: https://elibrary.ru/item.asp?id=21501933

15. Morozova N. A., Osipenko L. E. System-functional approach to the analysis of the organization of educational problem-design and research activities in engineering classes within the framework of network interaction. Vestnik RIAT, 2018, no. 3, pp. 60-68. (In Russian) URL: https://elibrary.ru/item.asp?id=36885108

16. Nemirich T. N., Malanov I. A. Pre-professional training of rural schoolchildren. Education and law, 2018, no. 12, pp. 268-277. (In Russian) URL: https://elibrary.ru/item.asp?id=38052794

17. Kargapolova E. V., IAksyutina. V., Besedina I. V., Education in the modern Russian region: quality, state, problems, trends. Volgograd, Volgograd scientific publishing house Publ., 2013, 194 p. (In Russian) URL: https://elibrary.ru/item.asp?id=25114894

18. Kouzova E. A., Tyurina E. A., Solodkova M. I. Educational Technopark "TEMP": concept and models of implementation. Chelyabinsk, CHIPPKRO Publ., 2016, 104 p. (In Russian) URL: https://elibrary.ru/item.asp?id=26547319.

19. Ordina A. Yu. Project activity on chemistry with school children. Modern educational technologies in the world educational space, 2015, no. 1, pp. 118-123. (In Russian) URL: https://elibrary.ru/item.asp?id=25440556

20. Solodilov M. V. History and future of architecture of additional education on the example of an industrial city-children's Technopark. Samara, Samara state technical University Publ., 2020, pp. 140-149. (In Russian) URL: https://elibrary.ru/item.asp?id=42307370

21. Tugov I. I., Shakhramanyan M. A. And Profile and online education to prepare personnel to work in scientific and technical areas of Moscow. Vestnik VIESH, 2016, no. 2 (23), pp. 142-147. (In Russian) URL: https://elibrary.ru/item.asp?id=28213227 